DOI: https://doi.org/10.11144/Javeriana.upsy18-1.svag

\title{
Students' Views on the Acceptability of Government Databases for the Identification of Persons: A Pilot Study*
}

Puntos de vista de los estudiantes sobre la aceptabilidad de bases de
datos del gobierno para la identificación de personas: un estudio
piloto

Received: 24 September 2017 | Accepted: 12 April 2018

\author{
Nathalie Przygodzki-Lioneta \\ Université de Lille, Francia \\ ORCID: http://orcid.org/0000-0001-5387-6039 \\ MARINE MignOL \\ Hospital Center de Douai, Francia \\ FABIEN CADET \\ European Commission, Bélgica
}

a Correspondence author. Email: nathalie.lionetprzygodzki@univ-lille.fr

How to cite: Przygodzki-Lionet, N., Mignol, M., \& Cadet, F. (2019). Students' views on the acceptability of government databases for the identification of persons: A pilot study. Universitas Psychologica, 18(1) 1-9. https://doi.org/10.11144/Javeriana.upsy18-1.sv ag

\begin{abstract}
The present study aims at mapping French students' views regarding government databases. A set of realistic scenarios depicting a situation in which a government planned to create a new, more complete database on people, was created by varying the levels of diverse factors likely to have an impact of people's views: (a) the current situation in the country (secure vs. insecure), (b) the type of information gathered, whether it was only demographic information or more complete information, (c) the possibility of access to personal information, and (d) the level of confidentiality of the data; that is, whether they have been coded and only public authorities can have access to them or other bodies such as trade companies can take and use them. Four qualitatively different positions were found: Totally negative attitude (30\%), Depends on Guaranties (40\%) and Tolerable in some cases (26\%). Fourteen percent were undetermined. Left-wingers were most often of the idea that government databases were either unacceptable or at best tolerable, and Right-wingers and Centrists were most often of the idea that government databases could be acceptable to the essential condition that full confidentiality is guaranteed.
\end{abstract}

Keywords

Government databases; positions; France; confidentiality.

\section{RESUMEN}

El presente estudio tuvo como objetivo mapear las opiniones de los estudiantes franceses con respecto a las bases de datos del gobierno. Se creó un conjunto de escenarios realistas que representan una situación en la que un gobierno planeaba crear una base de datos nueva y más completa sobre personas, variando los niveles de factores que podrían tener impacto en las opiniones de las personas: (a) la situación actual en el país (seguro vs. inseguro), (b) el tipo de información recopilada, ya sea solo información demográfica o información más 
completa, (c) la posibilidad de acceso a información personal, y (d) el nivel de confidencialidad de los datos; es decir, si han sido codificados y solo las autoridades públicas pueden tener acceso a ellos $\mathrm{u}$ otros organismos como las empresas comerciales pueden tomarlos y usarlos. Se encontraron cuatro posiciones cualitativamente diferentes: actitud totalmente negativa (30\%), dependiente de garantías (40\%) y tolerable, en algunos casos (26\%). El 14 \% fue indeciso. En la mayoría de los izquierdistas la idea de las bases de datos del gobierno fue inaceptable o, en el mejor de los casos, tolerable, mientras que, en los derechistas y centristas, la mayoría de las veces, la idea de las bases de datos del gobierno fue aceptables con la condición esencial de que se garantizaba la confidencialidad total.

Palabras clave

bases de datos del gobierno; posiciones; Francia; confidencialidad.

Some government databases collect information on people living in the country. There are many reasons for governments to gather personal information about citizens, which range from public health concerns to national security concerns. Databases tend to be targeted at certain kind of people or certain kind of information. In the US, the SSN (Social Security Number) database contains the usual demographic information of all people with an SS number (e.g., place and date of birth, current residence). The NSA (National Security Agency) database contains details of telephone calls (e.g., telephone number, duration of the call) from more than one trillion calls through main operators in the country. In Germany, the National DNA database contains DNA profiles of people who have been arrested by the federal police. In France, the SAFARI database (Automated System for Administrative Files and Directories of Individuals) is a centralized system - a database of databases - allowing the consultation of databases from diverse administrative departments.

People's reactions to the existence of government databases are diverse. On the one hand, promotors of databases insist on their usefulness for identifying authors of transgressions, localizing illegal immigrants or preventing terrorist attacks. Their arguments are grounded in the ethical principle of benevolence.
It is for the good of citizens - their security, their well-being - that such administrative tools are created: These tools can, for example, allow preventing malevolent acts from various types of aggressors. On the other hand, detractors of databases insist on the potential threat to civil liberties that databases represent, and on the risks of errors that are inherent to the use of such large central data repositories. Their arguments are grounded on the ethical principle of autonomy (Beauchamp \& Childress, 2001): As far as they do not harm other people or the environment, citizens must be allowed to do what they like. Their arguments are also grounded on the non-malevolence principle: Databases have the potential to unwillingly harm people, besides that fact that they can be misused to harm people voluntarily. Their arguments are also sometimes grounded in the justice principle of autonomy: Why gathering information on certain categories of people and not on others?

The autonomy-benevolence tension has been the subject of several studies in empirical ethics. To what extent is it permissible to help terminally-ill patients to willingly put an end on their life (Mullet et al. 2016)? To what extent is it permissible to hospitalize potentially dangerous patients who have mental illness (Guedj, Sorum \& Mullet, 2012)? To what extent is it permissible to break confidentiality in order to protect someone's life (Olivari, Muñoz Sastre, Sorum \& Mullet, 2011? To what extent is it permissible not to tell the truth to terminally-ill patients (Kpanake, Sorum \& Mullet, 2016)? The findings from these studies show that people in the street can considerably disagree regarding the best course of action in such cases and that these disagreements are associated with many factors: their gender (e.g., Cano Romero, Muñoz Sastre, Quintard, Sorum \& Mullet, 2017), their age (e.g., Mazoyer, Muñoz Sastre, Sorum \& Mullet, 2017), their level of expertise (e.g., Pajot, Muñoz Sastre, $\&$ Mullet, 2017), their political orientation (e.g., Pajot, Muñoz Sastre, \& Mullet, 2017), their religious affiliation (Mullet et al., 2016), their religious involvement (e.g., Muñoz Sastre, Sorum $\&$ Mullet, 2016), or their culture (e.g., Kpanake, Igier, \& Muñoz Sastre, 2019), to quote only a few. 
There have been no empirical studies on people's positions regarding government databases. A study conducted in Venezuela (Guedez \& Mullet, 2014) and replicated in France (Guedez \& Mullet, 2018) has shown, however, that, in their conceptualization of human rights, people give as much importance to right to privacy (e.g., regarding sexual orientation) as to civil liberties (e.g., the right to express ones' opinion) or equality among citizens (e.g., equality between women and men). In other words, for people's views, the right to privacy are fundamental constituents of human rights.

\section{The Present Study}

Owing to its exploratory character, the present study was conducted on a sample of students. It was aimed at mapping French students' views regarding government databases. It used the same theoretical and methodological framework - Information Integration Theory (Anderson, 2008, 2016, 2018) — than the study by Guedez and Mullet (2014). A set of realistic scenarios depicting a situation in which a government planned to create a new, more complete database on people, was created by varying the levels of diverse factors likely to have an impact of people's views. The first factor considered in the scenarios was the current situation in the country (secure vs. insecure); that is, the government's probable aims to create a more operational database. It was introduced because promotors of databases' arguments usually center on security issues: fighting against terrorism, easing the work of the police and the justice system, detecting false identity papers, fighting against identity usurpation (Manenti, 2016).

The second factor considered in the scenarios was the type of information gathered, whether it was only demographic information or complete information involving biometric markers, telephone calls, or and travel habits. This factor is deemed to be an important one because the French National Commission on Informatics and Liberty (CNIL) has been specifically instituted in order to monitor the content of databases and prohibit the introduction of information that could be used to impair the right to privacy and civil liberties. The CNIL's missions are, among other things: (a) to verify the exactitude of the information, (b) to limit the aims of data gathering and to check whether the nature and amount of data collected match these aims, and (c) to limit the duration of conservation of these data to the attainment of these aims (CNIL, 2018).

The third factor considered was the possibility of access to personal information. According to the Law called "Informatics and Freedom” (Legifrance, 2012), all citizens have the right to access the data contained in their file and to obtain rectification or suppression of these data if they are erroneous. Finally, the fourth factor considered was about the level of confidentiality of the data; that is, whether they have been coded and only public authorities can have access to them or other bodies such as trade companies can take and use them. One of the CNIL's missions is to guaranty full confidentiality of the data (CNIL, 2018).

\section{Hypotheses}

Our hypotheses were based on findings from previous studies in empirical ethics that examined the tension between the autonomy principle and the other principles. Three qualitatively different positions were expected that correspond to the three contrasted positions found in these previous studies. For some people, government databases would have no utility and would impede human rights, and human development and survival. This position has been, for example, represented by the group called Pieces et Main-d'Oeuvre (Piece and Manpower) that went as far as requiring the suppression of identity cards and national census (PMO, 2013a; 2013b). Here, the autonomy principle was given priority over the other principles although arguments hostile to the creation and maintenance of databases have 
been presented as arguments favoring the people's well-being and the reduction of injustice.

For other people, databases would absolutely be needed as governance tools in a world that is each time more complex. In some cases, these people went as far as requiring the suppression of the CNIL (Barbaux, 2013). Here the benevolence principle has been given priority, without much regards for the autonomy principle. Finally, and probably for most people, the database would be needed to the extent that the information they contain would match the legitimate aims that have motivated their creation. In other words, when information would be limited to these aims, easily accessible to citizens, and fully confidential, databases would be considered as acceptable but when information would not apparently be limited to these aims, not easily accessible to citizens and, as a result, not easily rectifiable, and entirely confidentiality would not be guaranteed, databases would be considered as unacceptable. Here both principles -autonomy and benevolence- would be balanced.

Our second hypothesis was that political orientation would at least partly determine people's positions regarding the acceptability of government databases. Right-wing people would attribute more importance to the benevolence principle and, more often than others, have a favorable position toward databases. Left-wing people would attribute more importance to the autonomy principle and, more often than others, have an unfavorable position towards databases.

\section{Method}

\section{Participants}

Two hundred unpaid students (65\% female) participated in the present study. Their age ranged from 18 to $36(M=22.5, S D=2.01)$. The other demographic characteristics of the sample are shown in Table 1. The study conformed to the ethical recommendations of the French Society of Psychology; that is, full anonymity was respected, informed consent was obtained from all participants and they were free to stop the procedure at any time without any consequence.

\section{Material}

The material consisted of 24 cards showing a story of a few lines and a response scale. Each story had four critical items of information in the following order: (a) the security/insecurity context (terrorist attacks in different part of the country vs. no attacks), (b) type of information contained in the files (demographic and anthropometric information; demographic/ anthropometric information and information on travels in the country or abroad; or demographic/ anthropometric/travels information and video recording from surveillance cameras), (c) whether the person would have access to their files (no access vs. full access and possibility to rectify), and (d) level of confidentiality (public authorities only have access to the information in the files vs. public authorities have access to the information in the files and trade company have access to some information too).

\section{Table 1}

Demographic Characteristics of Participants. Composition of the Four Clusters

\begin{tabular}{|c|c|c|c|c|c|}
\hline \multirow[b]{2}{*}{ Characteristics } & \multicolumn{4}{|c|}{ Cluster } & \multirow[b]{2}{*}{ Total } \\
\hline & $\begin{array}{c}\text { Never } \\
\text { Acceptable }\end{array}$ & $\begin{array}{c}\text { Tolerable } \\
\text { in some } \\
\text { cases }\end{array}$ & $\begin{array}{l}\text { Depends } \\
\text { on } \\
\text { Guaranties }\end{array}$ & Undeterm. & \\
\hline \multicolumn{6}{|l|}{ Gender } \\
\hline Male & $20(29)$ & $17(24)$ & $27(39)$ & $6(8)^{\mathrm{a}}$ & 70 \\
\hline Female & $40(31)$ & $34(26)$ & $53(41)$ & $3(2)^{\mathrm{a}}$ & 130 \\
\hline $\begin{array}{l}\text { Year of Study } \\
\text { Before } \\
\text { Licence }\end{array}$ & $20(24)^{a}$ & $23(27)$ & $39(46)$ & $3(3)$ & 85 \\
\hline Licence & $17(26)^{\mathrm{b}}$ & $18(27)$ & $26(39)$ & $5(8)$ & 66 \\
\hline After Licence & $23(47)^{a b}$ & $10(20)$ & $15(31)$ & $1(2)$ & 49 \\
\hline \multicolumn{6}{|l|}{ Type of Study } \\
\hline Law & $32(32)$ & $24(24)$ & $40(40)$ & $4(4)$ & 100 \\
\hline Humanities & $28(28)$ & $27(27)$ & $40(40)$ & $5(5)$ & 100 \\
\hline \multicolumn{6}{|c|}{ Political Orientation } \\
\hline Exteme Left & $15(48)^{\mathrm{ad}}$ & $13(42)^{\mathrm{a}}$ & $3(10)^{a b c}$ & $0(0)$ & 31 \\
\hline Left & $19(34)^{\mathrm{b}}$ & $12(22)$ & $22(39)^{\mathrm{a}}$ & $3(5)$ & 56 \\
\hline Center & $23(28)^{\mathrm{cd}}$ & $18(22)^{a}$ & $36(45)^{b}$ & $4(5)$ & 81 \\
\hline Right & $3(9)^{a b c}$ & $8(25)$ & $19(59)^{C}$ & $2(6)$ & 32 \\
\hline Total & $60(30)$ & $51(26)$ & $80(40)$ & $9(4)$ & 200 \\
\hline
\end{tabular}

The 24 scenarios depicted in the card were obtained by the orthogonal crossing of the four factors: $2 \times 3 \times 2 \times 2=24$. One example 
of a scenario is the following: "The Republic of Laurancie is a parliamentary democracy. In the last ten years, the country has been the target of several terrorist attacks. The elected government plans to create a computerized file containing information on all the people currently living in the country. This file would contain people's demographic characteristics (e.g., current residence, geographic origin), anthropometric information (e.g., size, weight, eye color, fingerprints), and information on travels in the country and abroad. People would not have access to the information in their file. Only public authorities would have access to the information. The information would be coded in a way that full confidentiality is guaranteed. To what extent do you think that such a plan is acceptable?" The response scale was a 10-point scale with "Completely unacceptable" (1) at the left-hand extreme and "Fully acceptable" (10) at the right-hand extreme. The stories were written in French.

\section{Procedure}

Data collection took place in 2016 and 2017. It was completed in a quiet room in the university. Each person was tested individually. The procedure followed Anderson's (2008, 2018) recommendations for this kind of study. Participants took 20 to 30 minutes to complete the ratings. No participant voiced any complaint about the number of vignettes or the credibility of the proposed situations.

\section{Results}

A cluster analysis using the procedure recommended by Hofmans and Mullet (2013) was applied to the raw data to capture possibly different attitudes. As three qualitatively different positions were expected, a three-cluster solution was first tested. Then several other solutions were tested - a two-cluster one, a fourcluster one, a five-cluster one, and a six-cluster one - and findings were compared. The threecluster solution was discarded, and a four-cluster solution was retained because it was the one that produced the most significant findings. A threecluster solution could also have been retained, but this solution merged in a single cluster, two groups of participants who had different personal positions.

The main results corresponding to the four clusters are shown in Figure 1, with low acceptability ratings pooled across informative content and possibility of access. Four separate analyses of variance were conducted on the raw data of each cluster with a design of Security $x$ Information $\mathrm{x}$ Access $\mathrm{x}$ Confidentiality, $2 \times 3 \times 2$ $x 3$. Owing to the great number of comparisons conducted, the significance threshold was set at 0.001 . The main results are shown in Appendix A. Table 1 also shows the composition of the five clusters concerning participants' gender, year of studies, the type of studies and political orientation.

The first cluster $(N=60,30 \%$ of the sample) was the expected Never acceptable cluster. The overall mean was very low $(M=1.76)$. Despite that all acceptability ratings were low, ratings were significantly higher when (a) terrorists attacks have taken place $(M=1.89)$ that when the country was peaceful $(M=1.63)$, (b) when the information contained in the databases was limited $(M=1.96)$ than when it was extensive $(M=1.31)$, and (c) when full confidentiality was guaranteed $(M=2.22)$ than when it was not $(M$ $=1.30$ ). Besides, the effect of the information factor was stronger when confidentiality was guaranteed $(2.60-1.95=0.65)$ than when it was not $(1.33-1.27=0.04)$. Post-licence students and students whose political orientation was Left, or Extreme Left were more often members of this cluster than the license of pre-license students or students whose political orientation was Right.

The second cluster $(N=51,25 \%$ of the sample) was called Tolerable in some cases. The overall mean was low $(M=3.05)$. Acceptability ratings were significantly higher when (a) terrorists attacks have taken place $(M=3.42)$ that when the country was peaceful $(\mathrm{M}=$ 2.67), (b) when the information contained in the databases was limited $(M=3.53)$ than when it was extensive $(M=2.57)$, (c) when 
people have access to the content of the file $(M=3.35)$ than when they have no access $(M$ $=2.75)$, and (d) when full confidentiality was guaranteed $(M=4.08)$ than when it was not $(M$ $=2.02$ ). In addition, the effect of the information factor was stronger when confidentiality was guaranteed $(4.86-3.46=1.40)$ than when it was not $(2.20-1.89=0.31)$, and the effect of the access factor was stronger when confidentiality was guaranteed $(4.59-3.57=$ $1.02)$ than when it was not $(2.11-1.92=0.19)$. Mean ratings were higher than the middle of the acceptability scale in only one case: when attacks had taken place, information was limited, and access and confidentiality were guaranteed $(\mathrm{M}=$ 6.27). Students whose political orientation was Extreme Left were more often members of this cluster than students whose political orientation was Center.

\section{Figure 1}

The four clusters

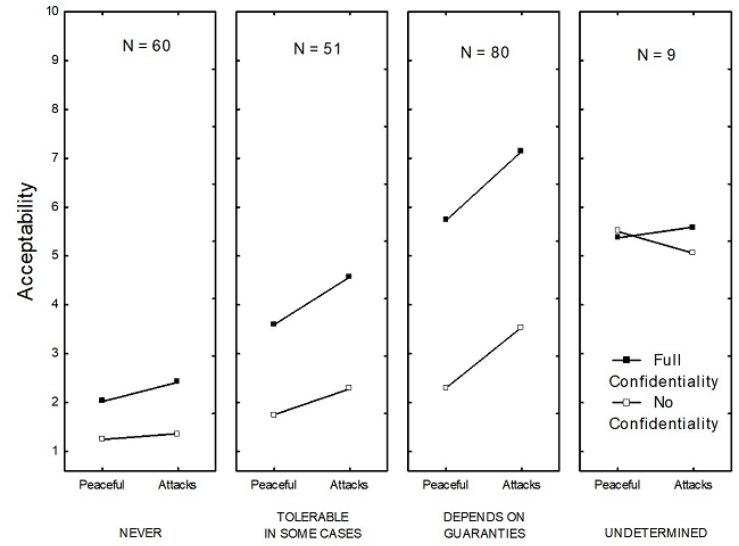

The third cluster $(N=80,40 \%$ of the sample) was the expected Depends on Guaranties cluster. The overall mean was higher than in both previous clusters $(M=4.68)$. Acceptability ratings were significantly higher when (a) terrorists attacks have taken place $(M=5.34)$ that when the country was peaceful $(\mathrm{M}=$ 4.01), (b) when the information contained in the databases was limited $(M=5.12)$ than when it was extensive $(M=4.30)$, (c) when people have access to the content of the file $(M=5.01)$ than when they have no access $(M=4.34)$, and (d) when full confidentiality was guaranteed (M
$=6.43)$ than when it was not $(M=2.92)$. In addition, the effect of the information factor was stronger when confidentiality was guaranteed $(7.15-5.83=1.40)$ than when it was not $(3.09-2.76=0.35)$. Mean ratings were higher than the middle of the acceptability scale in ten cases. Students whose political orientation was Extreme Left were less often members of this cluster than all other students.

The fourth cluster $(N=9,5 \%$ of the sample) was called Undetermined. The overall mean was very close to the middle of the response scale ( $M$ $=5.38$ ). No effect was significant. Male students were more often members of this cluster than female students.

An ANOVA was also performed on all the raw data. The design was Political Orientation $\mathrm{x}$ Security $\mathrm{x}$ Information $\mathrm{x}$ Access x Confidentiality, $4 \times 2 \times 3 \times 2 \times 2$. The results are shown in Table 2. Rightists' ratings were higher $(M=4.31)$ than Centrists' $(M=3.49)$, Leftists' $(M=3.31)$, and Extreme-Leftists' ( $M$ $=2.51$ ) ratings. No interaction involving this factor, however, was significant. The four withinsubject effects were significant as well as the three interactions involving the Confidentiality factor (see above).

\section{Discussion}

As expected, a cluster of students expressing a totally negative attitude to government databases was found. Even when all guarantees were present -full confidentiality and free access- and the information collected were only demographic, these students, mostly post-graduate or Left-wingers considered that the creation of government databases was unacceptable. In other words, even the innocuous SSN database would have to be abandoned. This means that the position advocated by groups such as $\mathrm{PMO}$, as extreme as it can appear, is not an isolated position: $30 \%$ of the students in our sample shared it.

As also expected, a Depends on Guaranties position was found. For the students sharing this position, mostly Right-wingers and Centrists, 
government database is acceptable to the condition that confidentiality is secured. Forty percent of students expressed this position, which is consistent with findings in most previous studies on empirical ethics conducted in France that show that people usually take circumstances into account before judging.

An intermediate, not expected position was found that was called Tolerable in some cases. This position was like the Depends on Guaranties position except that the acceptability ratings were located in the center of the acceptability scale; that is, in a zone that could be considered as a tolerability zone. For the students sharing this position, mostly Extreme-Left wingers, the creation of databases would only be, at best, a necessary evil.

Finally, the Always acceptable position was not found. No one student in the sample expressed the view that the creation of databases would be fully liberalized.

As expected, political orientation had a significant effect on students' positions. Leftwingers were most often of the idea that government databases were either unacceptable or at best tolerable, and Right-wingers and Centrists were most often of the idea that government databases could be acceptable to the essential condition that full confidentiality is guaranteed. Interestingly, political orientation only impacted on the overall attitude to databases; it did not impact on the importance attributed to their characteristics or the circumstances of their creation. Of the four factors considered in the present study, the most important was confidentiality (three-fourths of the explained variance) followed by security $(11 \%)$, political orientation (6\%), type of information (5\%) and access (3\%), and the order of importance of the four descriptive factors did not vary as a function of political orientation.

\section{References}

Anderson, N. H. (2008). Unified social cognition. New York, NY: Psychology Press.
Anderson, N. H. (2016). Information integration theory: Unified psychology based on three mathematical laws. Universitas Psychologica, 15(3), 1-7. http://dx.doi.org/10.11144/Jave riana.upsy 15-3.iitu

Anderson, N. H. (2018). Moral science. New York, NY: Psychology Press.

Barbaux, A. (2013, February 26). Pour Gilles Babinet, "il faut fermer la Cnil, c'est un ennemi de la Nation". L'Usine Nouvelle. Retrieved from https://www.usinenouvelle.com/articl e/pour-gilles-babinet-il-faut-fermer-la-cnilc-est-un-ennemi-de-la-nation.N192221

Beauchamp, T. L., \& Childress, J. F. (2001). Principles of biomedical ethics (5th ed.). New York, NY: Oxford University Press.

Cano Romero, M. D., Muñoz Sastre, M. T., Quintard, B., Sorum, P. C., \& Mullet, E. (2017). The ethics of post-operative pain management: Mapping nurses' views. International Journal of Nursing Practice, 23(2). https://doi.org/10.1111/ijn.12514

CNIL. (2018). Textes et décisions. [Texts and decision]. Retrieved from https://www.cnil. fr/en/media

Guedez, A. G., \& Mullet, E. (2014). Venezuelan adults' views on the indivisibility of Human Rights: A preliminary study. Psicologica: International Journal of Methodology and Experimental Psychology, 35, 621-633. Retrieved from https://www.uv.es/revispsi/a rticulos3.14/15GUEDEZ.pdf

Guédez, A. G., \& Mullet, E. (2018). French and Venezuelan people's conceptualization of human rights: Indivisibility and universality issues. Universitas Psychologica, 17(4), 1-9. https://doi.org/10.11144/Javeriana.ups y17-4.fvpc

Guedj, M., Sorum, P. C., \& Mullet, E. (2012). French lay people's views regarding the acceptability of involuntary hospitalization of patients suffering from psychiatric illness. International Journal of Law and Psychiatry, 35(1), 50-56. https://doi.org/10.1016/j.ijlp. 2011.11.010

Hofmans, J., \& Mullet, E. (2013). Towards unveiling individual differences in different 
stages of information processing: A clustering-based approach. Quality and Quantity, 47(1), 455-464. https://doi.org/10 $.1007 / \mathrm{s} 11135-011-9529-7$

Kpanake, L., Igier, V., \& Muñoz Sastre, M. T. (2019). Cultural differences in perceived appropriateness of breaking bad news to patients: A direct comparison of Togo and France. Universitas Psychologica, 18(2), 1-10. https://doi.org/10.11144/Javeriana.up sy18-2.cdpa

Kpanake, L., Sorum, P. C., \& Mullet, E. (2016). Breaking bad news to Togolese patients. Health Communication, 31, 1311-1317. Retrieved from http://r-libre.teluq.ca/1314/ 1/Breaking\%20Bad\%20News.pdf

Legifrance (2012). Délibération $n^{\circ} 2012-113 d u$ 12 avril 2012 portant autorisation unique de traitements de données à caractère personnel contenues dans des informations publiques aux fins de communication et de publication par les services d'archives publiques.

Manenti, B. (2016, November 2). Quatre fausses bonnes excuses pour ficher 60 millions de Français. Le Nouvel Observateur. Retrieved at https://www.nouvelobs.com/societe/201 61102.OBS0614/4-fausses-bonnes-excuses -pour-ficher-60-millions-de-francais.html

Mazoyer, J., Muñoz Sastre, M. T., Sorum, P. C., \& Mullet, E. (2017). Mapping French people and health professionals' positions regarding the circumstances of morphine use to relieve cancer pain. Journal of Supportive Care in Cancer, 25 (9), 2723-2731. https://doi.org/10.1007/s00520 $-017-3682-z$.

Mullet, E., Kpanake, L., Kamble, S., Ahmed, R. A., Bugay, A., Muñoz Sastre, M. T., \& Sorum, P. C. (2016). Mapping people's views regarding physician assisted suicide: A five-country study. International Psychology Bulletin, 20, 16-25.

Muñoz-Sastre, M. T., Sorum, P. C., \& Mullet, E. (2016). The acceptability of assisted reproductive technology among French lay people. Journal of Reproductive and Infant Psychology, 34, 329-342. https://doi.org/10. 1080/02646838.2016.1188279
Olivari, C., Muñoz Sastre, M. T., Guedj, M., Sorum, P. C., \& Mullet, E. (2011). Breaking patient confidentiality: Comparing Chilean and French viewpoints regarding the conditions of its acceptability. Universitas Psychologica, 10(1), 13-26. Retrieved from https://revistas.javeriana.edu.co/inde x.php/revPsycho/article/view/639

Pajot, E., Muñoz Sastre, M. T., \& Mullet, E. (2017). Mapping French people's views regarding posthumous reproduction. Journal of Reproductive and Infant Psychology, 35(5), 524-537. https://doi.org/10.1080/02 646838.2017 .1371283

PMO. (2013a). Contre le recensement. Paris : Le Monde à l'envers.

PMO. (2013b). Pour l'abolition de la carte d'identité. Paris : Le Monde à l'envers.

\section{Appendix A}

Main Results of the ANOVAs Conducted at the Cluster Level

\begin{tabular}{lrrrrr}
\hline Cluster and Factor & $d f$ & \multicolumn{1}{c}{$M S$} & \multicolumn{1}{c}{$F$} & \multicolumn{1}{c}{$p$} & $\eta^{2} \mathrm{p}$ \\
\hline Never Acceptable & & & & & \\
Security (S) & 1 & 23.77 & 12.93 & 0.001 & 0.18 \\
Information (I) & 2 & 15.90 & 21.50 & 0.001 & 0.27 \\
Access (A) & 1 & 13.42 & 8.35 & 0.01 & 0.12 \\
Confidentiality (C) & 1 & 301.58 & 127.90 & 0.001 & 0.68 \\
I x C & 2 & 11.26 & 13.64 & 0.001 & 0.19 \\
Tolerable in some cases & & & & & \\
Security (S) & 1 & 172.88 & 37.53 & 0.001 & 0.43 \\
Information (I) & 2 & 78.30 & 33.85 & 0.001 & 0.40 \\
Access (A) & 1 & 113.06 & 39.05 & 0.001 & 0.44 \\
Confidentiality (C) & 1 & 1305.31 & 463.34 & 0.001 & 0.90 \\
A x C & 1 & 53.54 & 22.13 & 0.001 & 0.31 \\
I x C & 2 & 30.89 & 19.39 & 0.00 & 0.28 \\
Depends on Guaranties & & & & & \\
Security (S) & 1 & 846.68 & 48.07 & 0.001 & 0.38 \\
Information (I) & 2 & 109.57 & 30.91 & 0.001 & 0.28 \\
Access (A) & 1 & 211.34 & 16.29 & 0.001 & 0.17 \\
Confidentiality (C) & 1 & 5925.59 & 352.87 & 0.001 & 0.82 \\
I x C & 2 & 40.48 & 19.67 & 0.00 & 0.20 \\
Undetermined & & & & & \\
Security (S) & 1 & 0.67 & 0.16 & 0.70 & 0.02 \\
Information (I) & 2 & 5.42 & 1.66 & 0.22 & 0.17 \\
Access (A) & 1 & 2.24 & 0.26 & 0.63 & 0.03 \\
Confidentiality (C) & 1 & 2.24 & 0.33 & 0.58 & 0.04 \\
Overall & & & & & \\
Political Orientation (P) & 3 & 417.35 & 9.27 & 0.001 & 0.12 \\
Security (S) & 1 & 732.19 & 74.93 & 0.001 & 0.28 \\
Information (I) & 2 & 168.86 & 68.70 & 0.001 & 0.26 \\
Access (A) & 1 & 214.09 & 30.37 & 0.001 & 0.13 \\
Confidentiality (C) & 1 & 4976.53 & 299.89 & 0.001 & 0.60 \\
I x C & 2 & 60.32 & 34.35 & 0.001 & 0.15 \\
A x C & 1 & 43.70 & 13.56 & 0.001 & 0.06 \\
S x C & 1 & 33,10 & 16,09 & 0.001 & 0.08 \\
\hline & & & & & \\
& & & & & \\
& & & & &
\end{tabular}

\section{Notes}

* Research article. The views that are expressed in this paper do not commit the European Commission. 